\title{
HONOUR AMONG BUSINESSPEOPLE: THE DUTY OF GOOD FAITH AND CONTRACTS IN THE ENERGY SECTOR
}

\author{
NeIl Finkelstein, BRANDON KaIN, Craig SPURN, \\ SÉAN C. O’NEILl, AND JUSTIN H. NASSERI ${ }^{*}$
}

\begin{abstract}
The recognition of a "duty of good faith" was a contentious issue for Canadian courts for many years, despite its recognition in other jurisdictions. In 2014, the Supreme Court of Canada recognized that parties to a contract have a duty to perform all contractual obligations in good faith. This article explores the history behind the "duty of good faith," the consequences of the Supreme Court's decision, and the impacts of the decision. This article also examines the effects of the decision as they relate to contracts fashioned in the energy sector, specifically in relation to rights of first refusal (ROFRs), authorizations for expenditure, and accounting and remittance of production sales proceeds.
\end{abstract}

\section{TABLE OF CONTENTS}

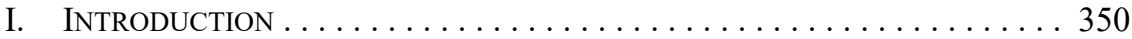

II. GOOD FAITH AND CONTRACT LAW PRE-BHASIN . . . . . . . . . . . 350

A. Good Faith in Contractual Performance:

A REVIEW of CANAdian CASE LAW . . . . . . . . . . . 351

B. The Debate About the Existence

OF A FREE-STANDING DUTY OF GOOD FAITH . . . . . . . . . . 358

C. 2013: UNCERTAINTY IN THE LAW

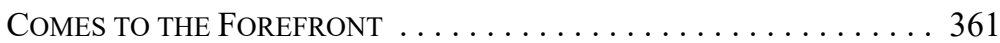

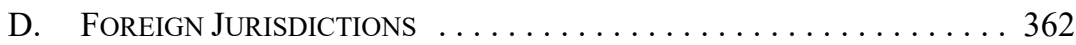

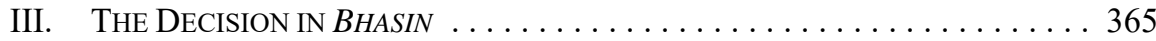

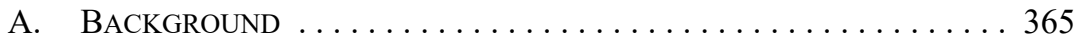

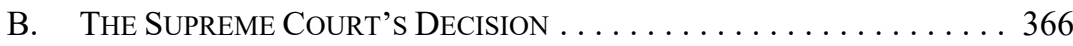

C. The Organizing Principle of Good Faith ExPlained . . . . . 367

D. The Duty of Honest Performance . . . . . . . . . . . . . . . . . 369

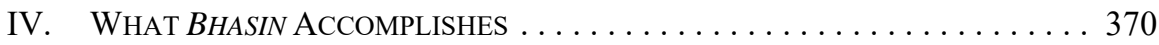

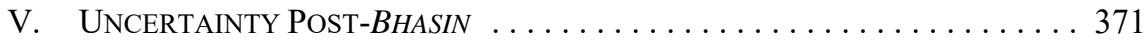

A. Silence on the Pre-Contractual Stage . . . . . . . . . . 371

B. SCOPE AND APPLICATION OF

DUTY OF HONEST PERFORMANCE . . . . . . . . . . . . . 372

C. UnCERTAinty About the Good Faith Principle . . . . . . . . . 373

VI. LESSONS FOR PARTIES SIGNING CONTRACTS

GOVERNED BY CANADIAN COMMON LAW . . . . . . . . . . . . . . 373

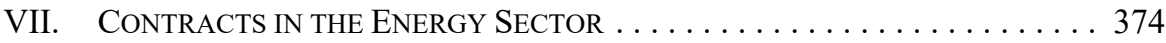

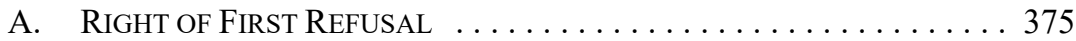

B. AUTHORIZATIONS FOR EXPENDITURE ........... 378

Neil Finkelstein, Brandon Kain, Craig Spurn, and Seán C O’Neill are partners and Justin H Nasseri is an associate at McCarthy Tétrault LLP. Finkelstein and Kain appeared as counsel before the Supreme Court of Canada for the successful appellant in Bhasin v Hrynew, 2014 SCC 71. The authors would like to acknowledge the assistance of Fraser Dickson in the research and editing of this article. 


\section{ACCOUnting AND REMitTANCE}

of Production SALES ProceEds . . . . . . . . . . . . . . . . 379

VIII. DRAFTING ENERGY CONTRACTS IN LIGHT OF BHASIN . . . . . . . . . . 380

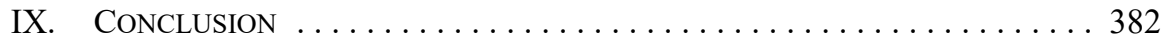

\section{INTRODUCTION}

Does the principle of good faith have a place in Canadian common law? Must parties perform their contractual obligations honestly? The answer to both of these questions, according to the Supreme Court of Canada in its groundbreaking decision Bhasin v. Hrynew, ${ }^{1}$ is a resounding yes. Bhasin, released on 13 November 2014, confirms that Canadian contract law is guided by an organizing principle of good faith in contractual performance and that parties have a duty to perform contractual obligations honestly. The Court described its decision as an "appropriate incremental step" in its development of the common law. ${ }^{2}$ This ruling is consistent with the notion, evident in over 200 years of Canadian contract law, that freedom of contract is constrained by reasonable limits, including basic requirements of honesty and fairness.

The Bhasin decision, called "perhaps the most important contract decision of the past 20 years," appellate judgments and academic debate that left the existence and scope of good faith obligations in contractual performance in flux. However, since the Supreme Court has framed both the principle of good faith and the duty of honest contractual performance in fairly broad terms, there is also some uncertainty about how the decision will be applied in future cases. Nevertheless, we can be certain that Bhasin will affect the way counsel advise their clients when entering into and performing contractual obligations. Parties to agreements governed by Canadian common law are well-advised to steer clear of any actions that might reasonably be interpreted as dishonest or made in bad faith.

This article will discuss both the principle of good faith and the duty of honest contractual performance as set out in Bhasin, and provide a commentary on how good faith in the performance of contracts was treated in Canadian law until Bhasin. The article will also explore how this landmark case might affect Canadian commercial law hereafter, with a focus on commonly used contract provisions in the energy sector.

\section{Good FAith ANd Contract LAW Pre-Bhasin}

As Justice Cromwell noted in the judgment, before Bhasin, the Supreme Court had not decided whether there was a general duty of good faith in contractual performance, and Canada's trial and appellate common law courts had reached different conclusions on this

2014 SCC 71, [2014] 3 SCR 494 [Bhasin SCC].

Ibid at para 92 .

David Dias, "SCC establishes a duty of honesty between contracting parties" (13 November 2014), Legal Feeds (blog), online: Canadian Lawyer Magazine <www.canadianlawyermag.com/legalfeeds/ 2379/scc-establishes-duty-of-honesty-between-contracting-parties.html $>$. See also Geoff R Hall, "Bhasin v. Hrynew: Towards an Organizing Principle of Good Faith in Contract Law" (2015) 30:2 BFLR 335 [Hall, "Good Faith"] (Hall describes this case as "landmark" at 335). 
issue. ${ }^{4}$ In one author's words, the "question of whether contracts should be interpreted as requiring good faith in the performance of contractual obligations [was], to put matters mildly, unsettled." Moreover, scholars have been divided on the issue of whether courts should recognize a freestanding duty of good faith in contractual performance. ${ }^{6}$ For instance, leading contracts professor Stephen Waddams opined that it would be better to "rest the obligation of good faith on an implied term of contract than on a legal rule external to the contract." ${ }^{, 7}$ On the other hand, Geoff Hall, a commercial litigator and authority on contractual interpretation, has said that the "argument in favour of a generalized duty arising in all cases seems to be more compelling" since contracts "work better when there is a duty of good faith performance." 8

As the following discussion will reveal, before Bhasin, Canadian case law on good faith varied widely — some cases suggested there was no duty of good faith in Canadian contracts law, some cases suggested an implied duty of good faith only in certain contractual contexts, and some cases even raised the possibility of a freestanding principle of good faith governing all Canadian contracts.

Although the concept of good faith has arisen in specific contexts such as employment contracts ${ }^{9}$ and franchise contracts, ${ }^{10}$ the following discussion will focus on general breach of contract cases that discuss a duty of good faith in performing obligations under an agreement.

\section{A. Good Faith in Contractual Performance: A Review of Canadian Case LaW}

In 2005, John D. McCamus identified three kinds of Canadian cases that engaged a duty of good faith in contractual performance. In each of these three categories, the circumstances of the cases gave rise to an implied duty of good faith: ${ }^{11}$

1. Cases that impose a duty to cooperate in fulfilling the objectives of the parties' agreement;

Bhasin SCC, supra note 1 at para 37.

Geoff R Hall, Canadian Contractual Interpretation Law, 2nd ed (Markham: LexisNexis, 2012) at 331

[Hall, Canadian Contracts]. See also Oz Optics Ltd v Timbercon Inc, 2011 ONCA 714, 343 DLR (4th) $443[\mathrm{Oz}$ Optics] ("[t]he obligation to act in good faith has been the subject of considerable discussion both by the judiciary and the legal academy. As things currently stand, it is difficult to ascertain in what circumstances it will be applied" at para 61).

6 See Michael G Bridge, "Does Anglo-Canadian Contract Law Need a Doctrine of Good Faith?" (1984) 9:4 Can Bus LJ 385 at 412-13 (where Bridge argues that further recognition of a good faith duty in contract law could create uncertainty and protracted litigation). See also Don Clark, "Some Recent Developments in the Canadian Law of Contracts" (1993) 14:4 Adv Q 435 at 436-40.

7 SM Waddams, The Law of Contracts, 6th ed (Toronto: Canada Law Book, 2010) at para 550. See also Mesa Operating Limited Partnership v Amoco Canada Resources Ltd(1994), 149 AR 187 (CA) [Mesa], leave to appeal to SCC refused, 24123 (6 October 1994); Slate Ventures Inc v Hurley (1996), 139 Nfld \& PEIR 235 (Nfld SC (TD)), aff'd (1997), 156 Nfld \& PEIR 304 (Nfld CA).

$8 \quad$ Hall, Canadian Contracts, supra note 5 at $346,349$.

$9 \quad$ Hall, Canadian Contracts, ibid at 337. See also Wallace v United Grain Growers Ltd, [1997] 3 SCR 701 .

$10 \quad$ See Shelanu Inc v Print Three Franchising Corp (2003), 226 DLR (4th) 577 (Ont CA).

11 John D McCamus, The Law of Contracts (Toronto: Irwin Law, 2005) at 784-805. See also Hall, Canadian Contracts, supra note 5 at 346. 
2. Cases that place consistency limits on the exercise of discretionary powers under a contract; and

3. Cases that preclude parties from evading contractual obligations.

This three-pronged classification system was subsequently adopted by the Ontario Court of Appeal, as well as the Supreme Court in Bhasin. ${ }^{12}$ As the following discussion will demonstrate, these are not watertight categorizations. Indeed, several of the cases discussed below could fall into two or three of the stated categories. It is, however, an intelligible way of examining the leading pre-Bhasin cases where an implied duty of good faith was found to exist in Canadian contract law.

\section{DUTY TO COOPERATE}

In "duty to cooperate" cases, courts infer a duty of good faith from contractual provisions that suggest some measure of cooperation between the parties. A compelling example can be found as early as 1978, in Dynamic Transport Ltd. v. O.K. Detailing Ltd., where a purchase and sale of land contract contained a condition precedent that subdivision approval had to be obtained, but the contract did not clarify whether it was the vendor or the purchaser who was responsible for obtaining the approval. ${ }^{13}$ The Supreme Court unanimously held that, since the vendor proposed to carry out the subdivision before the sale, he was under an implied obligation to use best efforts to obtain the approval. ${ }^{14}$ Although the Court did not develop a freestanding duty of good faith, this case underscored that there is some notion of good faith underlying the analysis of parties' obligations in a contract.

Good faith in the context of contractual performance was more explicitly discussed in the Nova Scotia trial decision of Gateway Realty Ltd. v. Arton Holdings Ltd. and LaHave Developments Ltd. (No. 3). ${ }^{15}$ In that case, Arton had become the assignee of an anchor lease in Gateway's mall, for a space formerly occupied by Zellers, without any obligation to occupy the space or seek a subtenant. Despite Arton and Gateway entering into an agreement under which the parties would use their best efforts to lease the old Zellers space, Arton would not sublet to any tenants that it felt would give Gateway a competitive advantage. Gateway sued Arton for breach of contract, alleging that Arton was blatantly refusing to use best efforts to occupy the space and that, in the alternative, it had breached a duty of good faith in performing the contract. Although Justice Kelly found that Arton had breached the

12 See Bhasin SCC, supra note 1 at para 47; CivicLife.com Inc v Canada (Attorney General) (2006), 215 OAC 43 (CA) at para 49 [CivicLife].

[1978] 2 SCR 1072 [Dynamic Transport].

Ibid at 1084-85:

The vendor is under a duty to act in good faith and to take all reasonable steps to complete the sale. I cannot accept the proposition that failure to fix responsibility for obtaining planning approval renders a contract unenforceable. The common intention to transfer a parcel of land in the knowledge that a subdivision is required in order to effect such transfer must be taken to include agreement that the vendor will make a proper application for subdivision and use his best efforts to obtain such subdivision. This is the only way in which business efficacy can be given to their agreement. In the circumstances of this case, the only reasonable inference to be drawn is that an implied obligation rested on the vendor to apply for subdivision.

(1991), 106 NSR (2d) 180 (SC (TD)) [Gateway TD], aff’d (1992), 112 NSR (2d) 180 (SC (AD)) [Gateway AD]. 
"best efforts" clause, he also discussed the existence of good faith in Canadian contract law, finding that:

The law requires that parties to a contract exercise their rights under that agreement honestly, fairly and in good faith. This standard is breached when a party acts in a bad faith manner in the performance of its rights and obligations under the contract. "Good faith" conduct is the guide to the manner in which the parties should pursue their mutual contractual objectives. Such conduct is breached when a party acts in "bad faith" - a conduct that is contrary to community standards of honesty, reasonableness or fairness. The insistence on a good faith requirement in discretionary conduct in contractual formation, performance, and enforcement is only the fulfillment of the obligation of the courts to do justice in the resolution of disputes between contending parties. ${ }^{16}$

Justice Kelly clearly believed that there was an obligation of good faith performance, to rectify "bad faith" conduct, and to fulfill a basic notion of honesty and fairness in contract law. The Court's stance was likely bolstered by the existence of provisions that specifically committed the parties to make best efforts to perform certain obligations. Conduct contrary to these provisions undermined basic standards of fairness and honesty and smacked of bad faith. The Nova Scotia Court of Appeal affirmed Justice Kelly's decision, but it did not comment on the duty of good faith. ${ }^{17}$ Justice Kelly's reasoning was more explicit than Dynamic Transport in suggesting that good faith was a stand-alone principle or standard in contract law. At the time Gateway AD was decided in 1991, Canadian law was already rife with examples of courts inferring some good faith obligation in contractual contexts. ${ }^{18}$ After reviewing some of these authorities, Justice Kelly opined that, beyond basic ethics, a good faith obligation was of "commercial value to the business community to have their commercial relationships ... and their contractual performance guided by some good faith requirement." 19

Thus, when a contract expressly creates an obligation to make best efforts to do something, or to cooperate towards a specific end, courts imply an obligation of good faith in the performance of these terms. The implication of a good faith requirement ensures that

16 Gateway TD, ibid at 191-92 [emphasis added].

17 Gateway AD, supra note 15.

18 Gateway TD, supra note 15 at paras 42-47. See also Bercovici v Palmer (1966), 59 DLR (2d) 513 (Sask CA); Atmospheric Diving Systems Inc v International Hard Suits Inc, [1994] 5 WWR 719 (BCSC); Dynamic Transport, supra note 13 (Justice Dickson held that a "vendor [was] under a duty to act in good faith and to take all reasonable steps to complete the sale" at 1084). See also Greenberg v Meffert (1985), 18 DLR (4th) 548 at 553-56 (Ont CA) [Greenberg], leave to appeal to SCC refused, 19563 (10 December 1985). Justice Belobaba of the Ontario Superior Court of Justice, who was a law professor at the time, also advocated for recognition of a general duty of good faith in contract law in 1985: see Edward P Belobaba, "Good Faith in Canadian Contract Law" in Special Lectures of the Law Society of Upper Canada ed, Commercial Law: Recent Developments and Emerging Trends (Don Mills, Ont: Richard DeBoo, 1985) 73.

19 Gateway TD, ibid at para 66:

To insist that parties to a contract not act in bad faith can be based on more than the pursuit of some ethical values in business relationships. Surely it is of commercial value to the business community to have their commercial relationships, their contractual drafting, and their contractual performance guided by some good faith requirement. They can then rely on such a legal principle rather than incur costs in an attempt to protect themselves from bad conduct. In an era of changing commercial circumstances, long-term contracts cannot always anticipate future economic commercial and merchandising trends. These make it difficult for the businesses and their counsel to incorporate into a contract protection from uncertain risks. A climate of law where counsel are urging their clients to act fairly, or at least not in "bad faith", is a climate where business disputes will more likely be resolved, and such disputes and the costs arising from them more likely avoided. 
unambiguous promises are fulfilled in an honest manner. This is a sensible approach, and one that upholds the reasonable expectations of contracting parties by prohibiting arbitrary or capricious evasion of a contract's terms. Without this implied term of good faith, there might be an incentive to agree to broadly framed commitments in contracts, and then to perform them in a lacklustre or insufficient manner.

\section{DISCRETIONARY POWERS}

Courts have also implied a good faith duty in several cases concerning a party's abuse of a discretionary contractual power.

Mesa is an excellent example of good faith being implied to limit contractual discretion in the oil and gas sector. ${ }^{20}$ Mesa had an agreement with Amoco whereby it sold mineral interests in several parcels of land to Amoco, but retained a 12.5 percent overriding royalty on the proceeds of production from the properties. Amoco had a right to pool or unitize any portion of the properties, and after drilling a successful gas well on one of the properties (a half section of land), it pooled it with the related half sections of land that it also had exclusive ownership over in order to form a gas well production spacing unit. Instead of allocating production between the royalties on the basis of the actual location of the relevant gas pool or reserves (that is, a reserves pooling), Amoco pooled such parcels on an aerial or acreage basis (that is, production would be allocated to the two half sections forming the spacing unit based on the surface acreage of each) thereby entitling Mesa to its royalty only in respect of 50 percent of the production from the gas well. Mesa sued Amoco, and at trial, the judge found that Amoco had breached its contract, as the vast majority of the reserves associated with the subject gas well were located on the property that was subject to Mesa's royalty, and, in the circumstances, Amoco's acreage-based approach to pooling was inappropriate under oil and gas industry standards. The Court of Appeal upheld the trial judge's findings, ruling that Amoco had breached a contractual duty of good faith in its pooling practices and should have carried out a reserves-based pooling. ${ }^{21}$

The Court of Appeal clarified that a "general obligation expressed in terms of good faith is not an obvious part of contract law in England and Canada." ${ }^{22}$ Instead of framing good faith as a general principle of contract law, the Court held that it was the contract between Mesa and Amoco that "created certain expectations between the parties about its meaning, and about performance standards. If those expectations are reasonable, they should be enforced because that is what the parties had in mind." ${ }^{.23}$ Since the parties' contract was developed in the oil and gas industry, the Court found that well-established industry practices were relevant in assessing the parties' expectations, and that Mesa consequently had a reasonable expectation that Amoco would follow proper pooling practices. ${ }^{24}$ Clearly, the Court was exercising judicial restraint by veering away from any discussion of good faith as a stand-alone principle in contract law. In fact, Justice Kerans flagged the concern that "good

Supra note 7.

Ibid at paras 1-15.

Ibid at para 16 .

Ibid at para 19.

Ibid at paras 20-21. 
faith" may be too vague a term, one that could "encourage judges to wander unnecessarily far into the thicket of extra-contractual rules of conduct." 25

There are several other reported cases in which courts discuss good faith in the context of exercising a discretionary power. While these decisions consistently find that a defendant has breached an implied good faith obligation, the source of that obligation is from the terms of the contract rather than an overarching legal principle. ${ }^{26}$ For example, in Mitsui, cited by the Supreme Court in Bhasin, a company called Pegasus leased two helicopters from Mitsui under lease agreements that provided Pegasus with an option to purchase them at fair market value on the expiry of the lease. ${ }^{27}$ Although the Court was more concerned with analyzing whether the lease contracts were under the purview of the Conditional Sales Act, ${ }^{28}$ it did clarify that Mitsui could not "make any offer that it may feel is appropriate. It is contractually bound to act in good faith to determine the reasonable fair market value of the helicopters, which is the price that the parties had initially agreed would be the exercise price of the option." 29

This decision "shows how sensible the duty is. Without it, the lessor could have totally undermined the purpose of the option by refusing to cooperate with the valuation or by setting out exorbitant demands for the price to be paid to exercise the option." 30

Finally, in Greenberg, the Ontario Court of Appeal ruled that an employer, who had full discretion in setting the commissions in a salesperson employee's contract, was nevertheless "subject to a requirement of honesty and good faith.", 31

Collectively, these cases show that the courts will infer a good faith duty when parties are exercising broadly-framed discretionary provisions in a contract. It appears that this imposition of good faith is underwritten by the courts' desire to ensure fairness and reasonableness - and prevent dishonest or abusive behavior in the context of parties' agreements.

\section{Duty Not to Evade Contractual Obligations}

The third type of "implied duty of good faith" case identified by McCamus is one where an implied good faith duty prevents a party from doing something that may not be strictly prohibited by the terms of a contract, but which ultimately undermines its objectives. This is the broadest category of cases where pre-Bhasin courts found an implied duty of good faith to exist - and conceivably captures any case where a party to a contract acts in bad faith.

$25 \quad$ Ibid at para 18. See also Clark, supra note 6.

See e.g. Greenberg, supra note 18; Mason v Freedman, [1958] SCR 483, Judson J [Mason] (when exercising a repudiation of contract provision, a party must do so "reasonably and in good faith and not in a capricious or arbitrary manner" at 487). See also Mitsui \& Co (Canada) Ltd v Royal Bank of Canada, [1995] 2 SCR 187 [Mitsui].

Mitsui, ibid.

RSNS 1989, c 84.

Mitsui, supra note 26 at para 34 [emphasis added].

Hall, Canadian Contracts, supra note 5 at 334.

Greenberg, supra note 18 at 554. See also Brule Construction Ltd v Ottawa (City) (1991), 51 OAC 260

(CA); Imperial Oil Ltd v Young et al (1998), 167 Nfld \& PEIR 280 (Nfld CA). 
Mason, which the Supreme Court cited in Bhasin, provides an early example of this type of case. ${ }^{32}$ A vendor, regretting a contract he had entered into, attempted to repudiate it by failing to convey title in fee simple. He stated that he was unable to do so because he could not secure a bar of dower (which he required) from his wife. Justice Judson, writing for the majority, held that: "The plain uncontradicted fact is that the husband made no genuine attempt to obtain a bar of dower. He cannot take advantage of his own default and use the clause to escape his obligation. His duty was ... 'to ascertain, bona fide, whether his wife was willing to bar her dower, and to induce her by any reasonable sacrifice on his own part to do so." "33 The Court elaborated on the vendor's good faith obligation. Its reasoning also resonates with the "exercise of discretion" cases discussed above:

\begin{abstract}
When a vendor seeks to avoid a contract under this clause, which is obviously introduced for his relief, his conduct and his reasons for seeking to escape his obligations are matters of interest to the Court. There is a general principle to be deduced from the cases and it is the one I have already stated incidentally. A vendor who seeks to take advantage of the clause must exercise his right reasonably and in good faith and not in a capricious or arbitrary manner. This measure of his duty is the minimum standard that may be expected of him. ${ }^{34}$
\end{abstract}

This case, decided in 1958, is emblematic of the principle that, at the very least, an obligation of good faith can be implied to prevent a party from acting in a way that fundamentally undermines a contract.

The Ontario trial decision in GATX Corp. v. Hawker Siddeley Canada Inc. provides a more modern example of this principle. ${ }^{35}$ GATX held a 55 percent interest and Hawker Siddeley held a 45 percent interest in a company called CGTX. Under their shareholder agreement, GATX had a right of first refusal if Hawker Siddeley ever received an offer from a third party to purchase its shares in CGTX. If a third party made an offer to Hawker Siddeley, it had to offer GATX the right to buy those shares. ${ }^{36}$

When a company called Procor offered to buy Hawker Siddeley's shares, it structured a transaction whereby it would transfer its shares to a wholly-owned subsidiary company, Hawker Holdings, and allow Hawker Holdings to be acquired by Procor. This was a deliberate attempt to avoid triggering GATX's right of first refusal. Justice Blair, writing for the Court of Appeal, found that:

[I]t is patently clear on the Record, in my view, that the Procor offer was very carefully structured precisely to avoid the operation of GATX's Right of First Refusal. The nub of this lawsuit, of course, is to determine whether Hawker Siddeley and Procor were entitled to structure their agreement in such a manner, given the language of the Shareholders' Agreement; but I have no doubt that "getting around" the Right of First Refusal - to use a lay expression — or structuring the transaction in a fashion which would not attract the 
application of the Right of First Refusal - to put it in more formal legal terms, was a primary force behind the way in which the Procor Agreement was contrived. ${ }^{37}$

On the issue of good faith, the Court held that it was settled that the:

grantor of a right of first refusal must act reasonably and in good faith in relation to that right, and must not act in a fashion designed to eviscerate the very right which has been given. This is an illustration of the application of the good faith doctrine of contractual performance, which in my view is a part of the law of Ontario. $^{38}$

Although the Court's imposition of a good faith obligation was in the narrow context of a right of first refusal, Justice Blair's judgment exemplifies a notion of good faith that prohibits a party from evading his or her contractual promises.

In the Nova Scotia case Landymore v. Hardy, a family that owned two adjoining pieces of property sold one of them to the defendants, who agreed that the family had a first right of refusal if they ever decided to sell the land. ${ }^{39}$ The defendants attempted to transfer the property to a company they incorporated, called White Rose, and to sell a portion of it through that company. Justice Saunders found that:

The defendants' transfer to White Rose was motivated, in good measure, by the Hardys' desire to avoid or nullify the RFR. Further, the weight of evidence leads me to conclude that the defendants sought to use White Rose as a means of hiding their plans from the Landymores, presumably so that White Rose could sell a part of the property to a third party without giving notice to the Landymores such that by the time the Landymores found out, it would be too late for them to stop the sale. ${ }^{40}$

Justice Saunders concluded that "[t]he grantor of a right of first refusal is not entitled to frustrate it by conveying the property in such a way as to avoid having to give the right in the first place." 41

The cases above are entirely sensible and in keeping with parties' reasonable expectation that courts can and should prohibit conduct intended to enable a party to "weasel" out of its promises by inferring some measure of good faith obligation in how parties perform their contractual obligations. This concept was recently underscored in CivicLife, where the Court of Appeal partially allowed an appeal from a trial wherein the federal Crown, through Industry Canada, was found liable for breaching its duty of good faith to CivicLife, an Internet software developer. ${ }^{42}$

CivicLife and the Crown entered into contracts under which CivicLife would be the lead developer for an Internet portal for federal government websites, but where a company called SmartSources would provide CivicLife with components of the portal. When CivicLife and

Ibid at para 45 [emphasis added].

Ibid at para 72 .

(1991), 110 NSR (2d) (SC (TD)).

Ibid at para 115 [emphasis added]

Ibid at para 92 [citations omitted].

CivicLife, supra note 12. 
SmartSources were unable to co-operate, SmartSources provided the government with a portal, resulting in CivicLife's product being discarded. ${ }^{43}$ Justice Weiler, writing for the Court, noted that the contract's provisions reflected a clear intention that Industry Canada would facilitate cooperation between CivicLife and SmartSources in building a single portal. ${ }^{44}$ The Court held that Industry Canada's conduct undermined the contract's objectives and appeared "to be an abuse of its discretion under the contract." 45 Significantly, Justice Weiler also rejected the Crown's argument that an "entire agreement clause" could negate an implied duty of good faith or duty not to abuse a discretion. ${ }^{46}$ This is because in finding breaches of these duties:

The trial judge was not adding a term to the agreement that was not part of the parties' bargain; he was enforcing the reasonable expectations of the parties under the agreement. Second, neither of the entire agreement clauses here says their agreement contains no implied terms.... Third, an agreement in writing may be varied by a subsequent oral agreement. Here ... the parties orally agreed to vary their written arrangement and adopt a "minimal integration approach."47

This category of cases signifies the broadest and most expansive application of the good faith principle in contractual law prior to Bhasin. By implying a good faith obligation to prevent parties from acting in a way that undermines the objectives of a contract, courts can capture and rectify a wide range of dishonest, evasive, or "bad faith" conduct.

\section{B. The Debate About The EXISTence OF A FREE-STANDING DUTY OF GOOD FAITH}

In the previously discussed cases, the courts ruled or commented on a duty of good faith in a contract, but no free-standing duty was formally recognized or relied upon. In fact, Canadian appellate cases have repeatedly held that there was no free-standing good faith obligation. This has been the case even where the courts have implied the duty as a result of a specific context or criterion, such as where the objectives of the parties' contract or the nature of their relationship would be undermined without implying such a duty. ${ }^{48}$ Instead of

$43 \quad$ Ibid at paras $5-13$.

Ibid at para $47-48$.

Ibid at para 50 .

Ibid ("an entire agreement clause will not preclude the implication of a term of the contract, such as a duty of good faith performance or the duty not to abuse a discretion, because such term is already part of the existing agreement" at para 52).

Ibid [emphasis added].

See e.g. 978011 Ontario Ltd v Cornell Engineering Co (2001), 53 OR (3d) 783 (CA) [Cornell Engineering], leave to appeal to SCC refused, 28665 (1 November 2001). In this case, in which Cornell Engineering unilaterally terminated a services agreement with a numbered corporation, that corporation sought to enforce a clause that provided for compensation upon unilateral termination, and claimed damages in the alternative. After stating that the law regulates contractual conduct between individuals through three standards, namely unconscionability, good faith, and a fiduciary standard, the Court defined criteria that should be present for the law to require more than self-interested dealing on the part of a party:

If one party to a contract relies on the other for information, that reliance must be justified in the circumstances.... [T] he following five factors are indicative of situations where reliance is justified:

(1) A past course of dealing between the parties in which reliance for advice, etc., has been an accepted feature;

(2) The explicit assumption by one party of advisory responsibilities;

(3) The relative positions of the parties particularly in their access to information and in their understanding of the possible demands of the dealing;

(4) The manner in which the parties were brought together, and the expectation that could 
finding a free-standing duty of good faith, the courts inferred a good faith obligation based on specific contractual terms or contexts. This concept was confirmed in Transamerica Life Canada Inc. v. ING Canada Inc., where a majority of the Court of Appeal overturned a motions judge's decision to strike portions of ING's defence to Transamerica's breach of contract action. ${ }^{49}$ Although the Court said the doctrine of good faith was evolving, it stated unequivocally that:

Canadian courts have not recognized a stand-alone duty of good faith that is independent from the terms expressed in a contract or from the objectives that emerge from those provisions.... Rather, courts have implied a duty of good faith with a view to securing the performance and enforcement of the contract made by the parties, or as it is sometimes put, to ensure that parties do not act in a way that eviscerates or defeats the objectives of the agreement that they have entered into. ${ }^{50}$

On the facts of Transamerica, Justice O'Connor ruled that ING's pleadings should not have been struck since it was at least arguable that, for Transamerica to seek damages in an action instead of using a price adjustment mechanism set out in the parties' contract, was contrary to the objectives of their agreement. ${ }^{51}$ In subsequent decisions, the Ontario Court of Appeal confirmed the principle from Transamerica that there is no free-standing duty of good faith in contract law, but that such a duty could be derived from an express or implied term of the contract in the context of an alleged breach. ${ }^{52}$

Notwithstanding the authorities listed above, other appellate courts have suggested that there is room for a stand-alone duty of good faith. In Re Stelco Inc., a case decided after Transamerica, the Ontario Court of Appeal stated that the issue of a stand-alone duty of good faith existing independently from a contract is "not well settled." ${ }^{33}$ The Courts of Appeal for both British Columbia and New Brunswick have also suggested that there is at least a duty

create in the relying party; and

(5) [W]hether "trust and confidence" knowingly [has] been reposed by one party in the other.

The presence of one of these elements alone will not necessarily suffice to justify the imposition of a duty in law on the other. Dependence, influence, vulnerability, trust and confidence are of importance only to the extent that they evidence a relationship suggesting an entitlement not to be self-reliant.... While the relationship may be the foundation for the entitlement, in and of itself, the relationship does not create the entitlement. The entitlement arises either because one party has no ability to readily inform himself or herself by accessing important information or because one party has an inability to appreciate the significance of the information. That inability may be due to a cognitive disability or it may arise out of the circumstances created by the other party. To determine whether the entitlement is created, regard must be had to all the circumstances (ibid at paras 34-35 [citations omitted]).

(2003), 68 OR (3d) 457 (CA) [Transamerica]. Transamerica had agreed to purchase shares of a company, NN, from ING, but complained after closing about operational problems with NN and sued ING for misrepresentation. The ING pleadings at issue alleged that Transamerica had breached its duty of good faith in contract by: (i) failing to notify ING of problems it was aware of after the contract was signed, but before closing; (ii) failing to give ING prompt notice of the problems it had with NN and not consulting with it on remedial steps; and (iii) generally not acting fairly in its dealings with ING after the contract was signed (ibid at paras 5-7). Justice O'Connor held "that Canadian courts have proceeded cautiously in recognizing duties of good faith in the performance and enforcement of contracts" (ibid at para 51).

Ibid at para 53 [citations omitted] [emphasis added].

Ibid at paras 55-56.

See 1193430 Ontario Inc v Boa-Franc Inc (2005), 78 OR (3d) 81 (CA), leave to appeal to SCC refused, 31276 (13 April 2006); Jaffer v York University, 2010 ONCA 654, 326 DLR (4th) 148, leave to appeal to SCC refused, 33938 (3 March 2011).

53 (2006), 14 BLR (4th) 15 (Ont CA) at para 12. 
of good faith in Canadian common law when it comes to performing contractual obligations. $^{54}$

Furthermore, in both Peel Condominium Corp. No. 505 v. Cam-Valley Homes Ltd. ${ }^{55}$ and Nareerux Import Co. v. Canadian Imperial Bank of Commerce, ${ }^{56}$ the Ontario Court of Appeal appeared to endorse a freestanding duty to perform contractual obligations in good faith.

In Peel, the majority of the Court ruled that good faith was not applicable to the case at bar, as the trial judge had erroneously applied it to a pre-contractual phase of the parties' relationship. ${ }^{57}$ Nevertheless, when discussing contracts between developers and purchasers of condominiums, the Court stated that " $\mathrm{t}]$ he developer's good faith obligation, or duty, is to carry out the terms of the agreement and deliver whatever title the contract between the parties calls for." 58 This holding appears to endorse a duty to perform contractual promises in good faith.

The Court of Appeal was more explicit in Nareerux when it upheld the trial judge's findings that CIBC had breached an implied term of its contract with a shipping company that had accepted CIBC's letters of credit in an arrangement to ensure that CIBC's client could ship a large quantity of seafood from Thailand to the United States. Although the Court of Appeal acknowledged that "Canadian law has not yet recognized a stand-alone 'duty of good faith' in the performance of a contract that is independent from the terms of the contract,", 59 the Court provided a broad framework for cases where the duty could be implied:

Breach of a duty of good faith in the performance of a contract may be found where there is "evidence that some sort of bad motive — such as self-interest, ill will or a dishonest purpose - underlay a decision." Here, the Bank acted out of self-interest, as the trial judge found.

\begin{abstract}
The trial judge ultimately found that CIBC had breached its contractual obligations to Thai Fisheries both directly (by descending into the arena and participating in the arrangement with Robertson to frustrate the Special Conditions and using that non-compliance to refuse payment, while nonetheless applying the proceeds from the sale of shrimp supplied under the Letters of Credit to reduce Robertson's overdraft) and indirectly (by breaching an implied contractual duty of good faith not to act in a way that defeated the purpose of the contract). Having reached those conclusions, he was entirely justified in rejecting CIBC's attempts to rely upon the doctrine of strict compliance. ${ }^{60}$
\end{abstract}

Nareerux can be read to suggest that any conduct that defeats the purpose of a contract and was motivated by dishonesty triggers the breach of an implied duty of good faith. In this sense, it would be hard to imagine any cases where the duty would not exist if there was 99; Crawford et al v Agricultural Development Board (NB) et al (1997), 192 NBR (2d) 68 (CA) at paras $7-8$.

(2001), 53 OR (3d) 1 (CA) [Peel].

2009 ONCA 764, 97 OR (3d) 481 [Nareerux].

Peel, supra note 55 at para 42.

Ibid at para 43.

Nareerux, supra note 56 at para 69 [citations omitted]. Ibid at paras 72-73 [citation omitted] [emphasis added]. 
dishonest conduct at play. Consequently, Nareerux can be seen as an incremental step to recognizing an ever-present duty of good faith in contract law, even if it was dressed up as an implied duty.

\section{2013: UNCERTAINTY IN THE LAW COMES TO THE FOREFRONT}

2013 saw two of Canada's appellate courts come to directly opposing conclusions on the issue of good faith. On the one hand, in March 2013, the Alberta Court of Appeal released its decision in Bhasin v. Hrynew ${ }^{61}$ refuting the existence of a freestanding duty of good faith. On the other, in Barclays Bank PLC v. Metcalfe \& Mansfield Alternative Investments VII Corp., ${ }^{62}$ a decision rendered in July 2013, the Ontario Court of Appeal followed Justice Blair's reasoning in Nareerux and moved the law closer to recognizing a duty of good faith.

In the Bhasin CA decision, the Alberta Court of Appeal pronounced what it considered to be "settled legal rules," including that:

[1.] There is no duty to perform most contracts in good faith...

[2.] The only duty of good faith in employment contracts is relatively narrow...

[3.] Courts should not attempt after the fact to rewrite a contract to accord with what the court now thinks, or one party now believes, is more just or more businesslike, especially in the full light of hindsight. ${ }^{63}$

The Court stated that it could not rely upon several pieces of evidence, including what the parties' expectations were, to find an implied term of good faith, because the entire agreement clause in the contract Bhasin had with Can-Am "excludes 'terms' which are not express." ${ }^{\circ 4}$

However, in Barclays, a factually complex dispute arising out of asset-backed commercial paper instruments, the Ontario Court of Appeal invoked the principle of good faith when criticizing Barclays Bank for its conduct, noting that: "Barclays breached its duty of good faith," "B5 "Barclays' purported cure payment and the manner in which Barclays purported to terminate the Agreements defeated and eviscerated the very purpose of the agreement," "the trial judge's findings... justified the trial judge's conclusion that Barclays' Notice of Early Termination was fatally infected by a breach of duty of good faith." ${ }^{, 77}$ Although the Court of Appeal did not explicitly pronounce a stand-alone duty of good faith in contractual performance, it did hold that there is "an established principle that a duty of good faith arises when necessary to ensure that the parties do not act in a way that defeats the objects of the very contract the parties have entered." 68

\footnotetext{
61 2013 ABCA 98, 362 DLR (4th) 18 [Bhasin CA], rev’d Bhasin SCC, supra note 1.

622013 ONCA 494, 365 DLR (4th) 15 at para 134 [Barclays], leave to appeal to SCC refused, 35549 (16 January 2014).

Bhasin CA, supra note 61 at para 27 [citation omitted] [emphasis added].

Ibid at para 29.

Supra note 62 at para 136.

Ibid at para 137.

Ibid at para 146.

Ibid at para 134, citing Justice Blair's decision in Nareerux, supra note 56 at para 69.
} 
Barclays, like Nareerux, appears to stand for recognition of a broadly structured implicit duty of good faith - and with it, honesty - in performing contractual obligations. This is because conduct that is dishonest, or undertaken in bad faith, would virtually always defeat the object of any agreement that two parties enter into. The wronged party would surely always feel that such conduct undermines the objects of the contract.

On the other hand, the Alberta Court of Appeal in the Bhasin CA decision resisted any free-standing notion of good faith, emphasizing instead the parties' written agreements, and the principle that parties should be free to contract to the terms that bind them. Although Ontario courts had previously pushed the envelope on good faith in cases such as Nareerux, at the time there was also ample support for the principle that, if parties had expressly agreed to be bound by the terms of a contract, and the contract lacked provisions for a duty of good faith, then that duty could not be read into the agreement. For example, as the Ontario Superior Court of Justice held in ArcelorMittal Dofasco Inc. v. US Steel Canada Inc.:

\footnotetext{
There is no express duty of good faith set out in the Agreement, unlike the relevant documentation in Transamerica and Re Stelco, infra. The wording of the Termination Right is not qualified in any manner by duties of good faith or reasonableness.
}

\footnotetext{
More generally, I know of no legal principle that imposes a duty of good faith on sophisticated commercial parties, who have chosen not to commit to such an obligation in the contractual arrangements among themselves, solely by virtue of the continuity of their relationship. To do so would involve the Court in arbitrarily re-writing the commercial arrangements among the parties. ${ }^{69}$
}

In contrast, the Ontario Court of Appeal in Barclays appeared to be more concerned with the impact that bad faith conduct has on the foundations of any contract between two parties. If this sort of conduct obstructs the very objectives of the parties' contracts, it becomes "necessary," on the Court's reasoning, to infer a term of good faith governing the performance of the contract.

If it was not clear before that Canadian courts were divided (or at least lacking clarity) on good faith and contractual performance, the decisions in Bhasin CA and Barclays underscored the need for the Supreme Court of Canada to clarify the law.

\section{FOREIGN JURISDICTIONS}

It merits mention that, when the Supreme Court released its decision in Bhasin, several foreign jurisdictions had already recognized a duty of good faith in the performance of 
contractual obligations. ${ }^{70}$ In fact, as the Supreme Court noted, common law Canada's two major trading partners — the US and Quebec — both recognize a duty to perform agreements in good faith. ${ }^{71}$

Although Quebec is technically not a foreign jurisdiction, it operates under a civil law regime, and is consequently distinct from the rest of Canada's provinces and territories. In Quebec, "good faith ... is a general principle clearly recognized and given express sanction by the introductory provisions of the Civil Code."72 And even without those express provisions, the Supreme Court held that a general duty of good faith should be implied under article 1024 of the former Civil Code of Lower Canada: ${ }^{73}$

[A]greements must be performed in good faith. It is true that no provision is to be found in our Civil Code which states this expressly ... but ... the principle is axiomatic ... Trudel ... is of the opinion that our legislators found such a provision superfluous ... in a legal institution which is based on confidence and [good] faith.... "There is no species of agreement in which it is not implied that one party owed good faith to the other party.", 74

Similarly, in the US, section1-304 of the Uniform Commercial Code enacted by numerous states provides that "[e]very contract or duty" within it "imposes an obligation of good faith in its performance and enforcement," "75 and section 205 of the Restatement (Second) of Contracts affirms that "[e]very contract imposes upon each party a duty of good faith and fair dealing in its performance and its enforcement."

See e.g. Yam Seng Pte Ltd v International Trade Corporation Ltd, [2013] EWHC 111, [2013] 1 CLC 662 (QB) at para 124 [Yam Seng]; United Nations Convention on Contracts for the International Sale of Goods, 11 April 1980, 1489 UNTS 3 art 7(1) (entered into force 1 January 1988); International Institute for the Unification of Private Law, UNIDROIT Principles of International Commercial Contracts 2010 (Rome: UNIDROIT, 2010), art 1.7; Commission on European Contract Law, Principles of European Contract Law Parts I and II, Ole Lando \& Hugh Beale, eds (The Hague: Kluwer International, 2000), arts 1:106(1), 1:201.

71 Bhasin SCC, supra note 1 at paras 83-85. The Court explained that "[t]he Civil Code of Quebec recognizes a broad duty of good faith which extends to the formation, performance and termination of a contract and includes the notion of the abuse of contractual rights" (ibid at para 83). When discussing American law, the Court stated:

In the United States, $§ 1-304$ of the U.C.C. provides that "[e]very contract or duty within the Uniform Commercial Code imposes an obligation of good faith in its performance and enforcement." The U.C.C. has been enacted by legislation in all 50 states. While the provisions of the U.C.C. apply only to commercial contracts, $\$ 205$ of the Restatement (Second) of Contracts (1981) provides for a general duty of good faith in all contracts. This provision of the Restatement has been followed by courts in a vast majority of states (ibid at para 84).

The Court also notes that "very broad conceptions of the duty of good faith have not impeded contractual activity or contractual stability" in Quebec or the US (ibid at para 85 [footnotes omitted]). Banque nationale de Paris (Canada) v 165836 Canada Inc, 2004 SCC 37, [2004] 2 SCR 45 at para 69 arts 6, 7, 1375 CCQ; Hall, "Good Faith," supra note 3 (explaining that the "hostility of Canadian common law courts to the concept of a duty of good faith stood in stark contrast to Quebec civil law, which considers good faith a central tenet of contract law governing all aspects of a contractual relationship" at 338).

73 Art 1024 CCLC, as repealed by CCQ:

The obligation of a contract extends not only to what is expressed in it, but also to all the consequences which, by equity, usage or law, are incident to the contract, according to its nature.

$74 \quad$ National Bank of Canada $v$ Soucisse, [1981] 2 SCR 339 at 356 [citations omitted] [emphasis added] See also Bank of Montreal v Kuet Leong Ng, [1989] 2 SCR 429 at 436; Houle v Canadian National Bank, [1990] 3 SCR 122 at 145-46, 156-58; National Bank of Canada v Corbeil, [1991] 1 SCR 117 at 131; Bank of Montreal v Bail Ltée, [1992] 2 SCR 554 at 582, 586.

75 UCC $\$ 1-304(2001)$.

76 Restatement (Second) of Contracts $\S 205$ (1981). See also Wigand v Bachmann-Bechtel Brewing Co, 118 NE 618 at 619 (NYCA 1918); Kirke La Shelle Co v Paul Armstrong Co, 188 NE 163 at 168 (NYCA 1933); Market Street Associates LLP v Frey, 941 F (2d) 588 at 595 (7th Cir 1991). 
Turning to other common law jurisdictions, Australian appellate courts have also recognized a duty of good faith in contractual performance, and English courts are beginning to do the same. ${ }^{77}$ In the English case Yam Seng, Justice Leggatt stated:

$[T]$ here is ... nothing novel or foreign to English law in recognising an implied duty of good faith in the performance of contracts. It is consonant with the theme identified by Lord Steyn as running through our law of contract that reasonable expectations must be protected... [S] uch a concept is ... already reflected in several lines of authority that are well established.

I respectfully suggest that the traditional English hostility towards a doctrine of good faith in the performance of contracts, to the extent that it still persists, is misplaced. ${ }^{78}$

Most recently, in MSC Mediterranean Shipping Company S.A. v. Cottonex Anstalt, Justice Leggat noted that the common law world is increasingly recognizing the "need for good faith in contractual dealings" and that "[f]urther impetus has been given to this development by the unanimous judgment of the Supreme Court of Canada in [Bhasin].,"79

And while the law is still developing in Australia, it is at least clear that the duty of good faith requires honest conduct in contractual dealings. ${ }^{80}$ In Sino Iron Pty Ltd. v. Mineralogy Pty Ltd. (No. 2), the Supreme Court of Western Australia acknowledged that implying a good faith term into commercial contracts "remains a vexed issue" 81 in Australian common law, but cited to Bhasin and acknowledged that, at a minimum, there is a clear "duty to exercise contractual powers [honestly] and reasonably ... [and] to cooperate to achieve contractual objectives." 82

The fact that so many jurisdictions are leaning towards, or have already adopted, a general principle of good faith in contractual performance validates the Supreme Court's approach in Bhasin.

United Group Rail Services Ltd v Rail Corp (NSW), [2009] NSWCA 177, 74 NSWLR 618 at paras 58-61, 100-101; Cordon Investments Pty Ltd v Lesdor Properties Pty Ltd, [2012] NSWCA 184, 2012 WL 2407483 at para 144; Bobux Marketing Ltd v Raynor Marketing Ltd, [2001] NZCA 348, [2002] 1 NZLR 506 at paras 33-49, 81 .

78 Yam Seng, supra note 70 at paras 145, 153. See also Philips Electronique Grand Public SA v British Sky Broadcasting Ltd (1994), [1995] 3 EMLR 472 at 483-84 (CA); Smith v Bank of Scotland, [1997] SC (HL) 111 at 120-21; Hayes $v$ Willoughby, [2013] UKSC 17, [2013] 1 WLR 935 at para 14; Michael Furmston, Cheshire, Fifoot \& Furmston's Law of Contract, 16th ed (Oxford: Oxford University Press, 2012) at 33-34; Roger Brownsword, "Positive, Negative, Neutral: The Reception of Good Faith in English Contract Law" in Roger Brownsword, Norma J Hird \& Geraint Howells, eds, Good Faith in Contract: Concept and Context (Aldershot: Dartmouth, 1999) 13 at 39; Mid Essex Hospital Services NHS Trust v Compass Group UK and Ireland Ltd, [2013] EWCA Civ 200, [2013] BLR 265 at paras $105,150$.

79 [2015] EWHC $283(\mathrm{Comm})$ at para 97.

80 Anthony Mason, "Contract, Good Faith and Equitable Standards in Fair Dealing" (2000) 116 Law Q Rev 66 at 76. See also Burger King Corp v Hungry Jack's Pty Ltd, [2001] NSWCA 187, 69 NSWLR 588 at para 171 .

81 [2014] WASC 444, 2014 WL 6693813 at para 239.

82 Ibid at para 242 [footnote omitted]. 


\section{THE DECISION IN BHASIN}

\section{A. BACKGROUND}

In Bhasin, the plaintiff, Harish Bhasin, brought an action for breach of contract against the Canadian American Financial Corporation (Can-Am). Since 1989, Bhasin was an "enrollment director" for Can-Am, meaning that he acted as a retail dealer and sold education savings plans to investors for Can-Am. ${ }^{83}$ Under this arrangement, Bhasin had developed a successful business with several employees. His contract with Can-Am provided that it would automatically renew at the end of the three-year term unless one of the parties provided a non-renewal notice six months in advance of the expiry. ${ }^{84}$ Significantly, the contract contained an "entire agreement clause" stipulating that no other express or implied contracts applied to the parties' agreement. ${ }^{85}$

Larry Hrynew, another enrollment director, was operating the largest agency under CanAm, and had attempted, unsuccessfully, to persuade Bhasin to merge his business with Hrynew's ${ }^{86}$ In 1999, Can-Am appointed Hrynew to be its provincial trading officer (PTO), providing him with the power and responsibility to audit Can-Am's enrollment directors, including Bhasin, who objected to a competitor being able to review his confidential business records. ${ }^{87}$ By 2000, Can-Am had considered arrangements that would involve Bhasin working for Hrynew's agency, and had not disclosed this information to Bhasin. Moreover, Can-Am "repeatedly misled Mr. Bhasin by telling him that Mr. Hrynew, as PTO, was under an obligation to treat the information confidentially and that the [Alberta Securities Commission] had rejected a proposal to have an outside PTO, neither of which was true." ${ }^{\prime 8}$

After Bhasin continued to refuse to allow Hrynew to audit his records, Can-Am provided Bhasin with a non-renewal notice in 2001, and Bhasin ultimately lost the value in his business because his sales agents were recruited by Hrynew's agency. ${ }^{89}$

The trial judge made a number of factual findings to the effect that Can-Am had dealt with Bhasin dishonestly during the events leading up to the non-renewal. ${ }^{90}$ However, although the trial judge also found that "it was an implied term of the contract that decisions about whether to renew the contract would be made in good faith" and that Can-Am "was in breach

Bhasin SCC, supra note 1 at paras 2-4 (although Bhasin's relationship with Can-Am bore similarities to a franchisee/franchisor relationship, their contract was a commercial dealership agreement, and not a franchise agreement governed by Alberta's Franchises Act, RSA 2000, c F-23).

Ibid at para 6.

Ibid at para 25

Ibid at para 9.

Ibid at para 10

Ibid at para 12 .

Ibid at paras 12-13.

Ibid. The Supreme Court stated:

The trial judge found that Can-Am acted dishonestly with Mr. Bhasin throughout the events leading up to the non-renewal: it misled him about its intentions with respect to the merger and about the fact that it had already proposed the new structure to the Commission; it did not communicate to him that the decision was already made and final, even though he asked; and it did not communicate with him that it was working closely with Mr. Hrynew to bring about a new corporate structure with Hrynew's being the main agency in Alberta. The trial judge also found that, had Can-Am acted honestly, Mr. Bhasin could have "governed himself accordingly so as to retain the value in his agency" (ibid at para 15 [citation omitted]). 
of the implied term of good faith," trial decision. ${ }^{92}$

The Court of Appeal found that the "duty of good faith in employment contracts could not be extended by analogy to other types of contract," 93 and that "a term cannot be implied where it goes against an express term of the contract." on respecting the provisions of the parties' formal contract, as it held that the "implication of a term of good faith also violated the entire agreement clause." ${ }^{\circ 5}$

\section{B. The SUPREMe CoURT's Decision}

After acknowledging that the concept of a duty of good faith in contract law had been subject to conflicting decisions and had been applied in different ways across different types of litigation, ${ }^{96}$ the Court stated that it "ought to develop the common law to keep in step with the 'dynamic and evolving fabric of our society' where it can do so in an incremental fashion and where the ramifications of the development are "not incapable of assessment.",97

The Court recognized that: (1) Canadian common law was uncertain on the issue of good faith in contracts; (2) the current approach to good faith performance of contractual obligations lacked coherence; and (3) the current law, which did not provide for any standalone duty of good faith in performing contracts, failed to account for commercial parties' reasonable expectations. ${ }^{98}$ As discussed above, the last point is an acknowledgment that the courts of common law Canada's two most significant trading partners - Quebec and the US - have recognized an obligation of good faith in the performance and enforcement of commercial agreements. ${ }^{99}$

The role of good faith and honesty in contractual performance was defined in two steps:

1. Step one is recognizing "that there is an organizing principle of good faith that underlies and manifests itself in various more specific doctrines governing contractual performance."

\footnotetext{
Ibid at para 14.

Ibid at para 16 .

Ibid at para 27.

Ibid at para 28.

Ibid.

Ibid at paras 25-39.

Ibid at para 40, citing, amongst other authorities, $R v$ Salituro, [1991] 3 SCR 654 at 670; Bow Valley Husky (Bermuda) Ltd v Saint John Shipbuilding Ltd, [1997] 3 SCR 1210 at para 93.

Bhasin SCC, ibid at para 41.

Ibid at paras 41,83-85. The Court explained that: "The Civil Code of Quebec recognizes a broad duty of good faith which extends to the formation, performance, and termination of a contract and includes the notion of the abuse of contractual rights" (ibid at para 83). When discussing American law, the Court stated:

In the United States, s. 1-304 of the U.C.C. provides that "[e]very contract or duty within the Uniform Commercial Code imposes an obligation of good faith in its performance and enforcement." The U.C.C. has been enacted by legislation in all 50 states. While the provisions of the U.C.C. apply only to commercial contracts, s. 205 of the Restatement (Second) of Contracts (1981) provides for a general duty of good faith in all contracts. This provision of the Restatement has been followed by courts in the vast majority of states (ibid at para 84). 
2. In step two, Justice Cromwell used an incremental approach to derive and recognize a general duty of honest contractual performance from the general organizing principle of good faith. ${ }^{101}$

Having recognized this duty to perform contractual obligations honestly, the Court turned its attention to Bhasin's case, noting that the trial judge had made findings of dishonesty on the part of Can-Am in the context of its desire to force a merger of Bhasin's agency with Hrynew's. ${ }^{102}$ Justice Cromwell "concluded that Can-Am's breach of contract consisted of its failure to be honest with Mr. Bhasin about its contractual performance and, in particular, with respect to its settled intentions with respect to renewal." 103 Consequently, the Court held that Bhasin was entitled to the value of his business around the time of Can-Am's breach, since, but for their conduct, he could have retained the value of his business, which the trial judge had assessed at $\$ 87,000 .^{104}$

\section{The Organizing Principle Of Good Faith ExPlained}

It is important to understand the distinctions between the broad organizing principle of good faith, and the narrower doctrine of honest performance, as set out in Bhasin.

Before explaining good faith as an "organizing principle," the Court explored the history of good faith in Canadian common law, noting that "it is a concept that underlies many elements of modern contract law."

In addition to McCamus's three categories of "implied duty of good faith" cases, the Court explained that good faith also underlies a number of legal doctrines, such as unconscionability, the rules of contractual interpretation, statutory duties and obligations, several specific contractual contexts, and certain classes of relationship such as employer and employee and insurer and insured. ${ }^{106}$ In all of these situations, the principle of good faith ensures that one party does not take undue advantage of another.

The Court acknowledged that good faith plays a role in respect of implied terms in contracts. For example, obligations of good faith underlie implied terms of contracts in certain contexts - where there are significant power imbalances, such as those between employer and employee, landlord and lessee, and insurer and insured. ${ }^{107}$ In these instances,

Ibid at para 92 .

Ibid at para 97. See also ibid at paras 98-103. Justice Cromwell concluded by finding that: As the trial judge found, this dishonesty on the part of Can-Am was directly and intimately connected to Can-Am's performance of the Agreement with Mr. Bhasin and its exercise of the non-renewal provision. I conclude that Can-Am breached the 1998 Agreement when it failed to act honestly with Mr. Bhasin in exercising the non-renewal clause (ibid at para 103).

Ibid at para 108 .

Ibid at paras $108-11$.

Ibid at para 42 [citations omitted]. See also Waddams, supra note 7 at para 550; McCamus, supra note 11 at $835-38$.

For the Court's survey of Canadian common law, see Bhasin SCC, ibid at paras 42-55.

Ibid at para 44. See also Honda Canada Inc v Keays, 2008 SCC 39, [2008] 2 SCR 362 (majority of the Court held that all employment contracts have an implied term of good faith with respect to termination); Fidler v Sun Life Assurance Co of Canada, 2006 SCC 30, [2006] 2 SCR 3 at para 63 (the Court held that an insurer must deal in good faith with an insured's claim and not investigate or assess a claim arbitrarily). 
it is the nature of the relationship between the parties which requires some good faith obligation on the part of the more powerful party so as to ensure fairness.

Furthermore, as we have seen above, the Court noted that courts in other commonwealth jurisdictions, such as the United Kingdom and Australia, have also increasingly leaned towards enforcing a good faith requirement in contractual performance. ${ }^{108}$

The Court used this survey to support its view that "Canadian common law in relation to good faith performance of contracts is piecemeal, unsettled and unclear." ${ }^{109}$ Justice Cromwell stated that "[c]ommercial parties reasonably expect a basic level of honesty and good faith in contractual dealings" since the growth of longer term commercial relationships is dependent upon some measure of trust and cooperation. ${ }^{110}$ Accordingly, Justice Cromwell recognized "an organizing principle of good faith that underlies and manifests itself in various more specific doctrines governing contractual performance."111

Not to be confused with a specific duty or doctrine, an organizing principle "states in general terms a requirement of justice from which more specific legal doctrines may be derived. An organizing principle therefore is not a free-standing rule, but rather a standard that underpins and is manifested in more specific legal doctrines and may be given different weight in different situations." 112

The good faith principle embodies the notion that parties should give appropriate regard to the legitimate contractual interests of their partners. This does not mean that one must act in his or her contracting partner's best interests. Rather, the principle requires parties to generally "perform their contractual duties honestly and reasonably and not capriciously or arbitrarily." 113 It prohibits parties from undermining each other's legitimate interests in bad faith. Justice Cromwell cautiously distinguished this principle from the "much higher obligations of a fiduciary," since the good faith principle does not engage duties of loyalty. ${ }^{114}$

Justice Cromwell also explained that the good faith principle manifests itself in existing doctrines about contexts where the law requires honesty and candour in contractual performance. This declaration signifies that the types of good faith cases discussed in this paper, such as the three classes of cases discussed by McCamus, as well as contracts in the insurance, labour, and housing contexts are all subsumed under the good faith principle's umbrella. The principle's application may also be more warranted in the context of long-term contracts requiring mutual cooperation rather than a one-time transaction. ${ }^{15}$

Ibid at para 60. See also Angela Swan \& Jakub Adamski, Canadian Contract Law, 3rd ed (Markham: LexisNexis Canada, 2012) at $\S 1.24$. This reasoning is supported by empirical evidence that suggests that contracting parties expect that their partners will exercise good faith when fulfilling their agreements: see Stewart Macaulay, "Non-contractual Relations in Business: A Preliminary Study" (1963) 28:1 American Sociological Rev 55 at 58; Vivien Goldwasser \& Tony Ciro, "Standards of Behaviour in Commercial Contracting" (2002) 30:5 Austl Bus L Rev 369 at 375-77.

Bhasin SCC, ibid at para 63 .

Ibid at para 64 [emphasis added].

Ibid at para 63.

Ibid at para 65 .

Ibid at para 69. 
Although "[g]enerally, claims of good faith will not succeed if they do not fall within these existing doctrines," Justice Cromwell acknowledged that the list is not closed, and that the law is open to incrementally recognizing new duties that emanate from the organizing principle. ${ }^{116}$ However, using the principle this way will be gradual and must be "consistent with the fundamental commitments of the common law of contract which generally places great weight on the freedom of contracting parties to pursue their individual self-interest."117

\section{The Duty of Honest Performance}

Having defined the broad, organizing principle of good faith in contract law, the Court proceeded to "hold that there is a general duty of honesty in contractual performance." 118 This duty of honesty "is a general doctrine of contract law that applies to all contracts" and consequently, parties are not free to exclude it (although, as we will see, parties apparently have some leeway to relax its application). ${ }^{119}$ The Court defined this doctrine as follows:

This means simply that parties must not lie or otherwise knowingly mislead each other about matters directly linked to the performance of the contract. This does not impose a duty of loyalty or of disclosure or require a party to forego advantages flowing from the contract; it is a simple requirement not to lie or mislead the other party about one's contractual performance. Recognizing a duty of honest performance flowing directly from the common law organizing principle of good faith is a modest, incremental step. ${ }^{120}$

As this excerpt suggests, the duty of honest performance is distinct from a duty of disclosure or fiduciary loyalty, and parties to contracts have no general duty to subordinate their interests to those of their contractual partners. ${ }^{121}$

According to the Court, this duty of honesty is consistent with the reasonable expectations of commercial parties who "would expect, at least, that the other party to a contract would not be dishonest about his or her performance." 122

Notwithstanding the significance of the Court's recognition of the new duty of honest contractual performance, Justice Cromwell did exercise judicial restraint when discussing the scope of the Court's decision. Although an entire agreement clause clearly cannot trump the doctrine of honest performance, Justice Cromwell clarified that the Court's decision:

would not rule out any role for the agreement of the parties in influencing the scope of honest performance in a particular context. The precise content of honest performance will vary with context and the parties should be free in some contexts to relax the requirements of the doctrine so long as they respect its minimum core requirements.

118 Ibid at para 73. See also ibid at para 74 (Justice Cromwell explains that this honesty doctrine operates irrespective of the intentions of the parties, and in this way, is analogous to equitable doctrines such as unconscionability).

$119 \quad$ Ibid at para 75 .

$120 \quad$ Ibid at para 73 [emphasis added].

$121 \quad$ Ibid at para 86.

122 Ibid at para 80 
Certainly, any modifications of the duty of honest performance would need to be in express terms. A generically worded entire agreement clause ... does not indicate any intention of the parties to depart from the basic tenets of honest performance. ${ }^{123}$

Thus, parties can relax the duty of honest performance to some extent by having express contractual terms that essentially set the rules by which they will conduct themselves.

\section{WHAT BHASIN ACCOMPLISHES}

The decision in Bhasin is laudable in that it has accomplished four important objectives. First, the decision serves as a map that brings some cohesion to the large and confusing body of case law on the application of good faith to contracts, which has been difficult, if not impossible, to reconcile. The decision solidifies good faith in contractual performance as a broader organizing principle of contract law, and establishes that specific duties can be incrementally derived from that principle. Existing legal contexts that call for good faith, such as when parties exercise discretion under a contract, or when employers negotiate new contracts with employees, are all subsumed under the principle. The first new, incrementally recognized duty under the principle requires parties to perform their contractual obligations honestly.

Second, the Court has clarified that the duty of honest performance will apply to all contracts, regardless of the parties' contractual terms and intentions. Parties must be honest with each other over all matters linked to performing their contractual obligations. This will undoubtedly impact the way parties conduct themselves, and counsel will need to be particularly vigilant in advising their clients to refrain from any behaviour that could be interpreted as deceptive or dishonest.

Third, in both recognizing the organizing principle of good faith and the duty of honest contractual performance, the Court has brought Canadian law in line with the reasonable expectations of contracting parties. This objective underlies the vast body of cases in which good faith obligations had been implied pre-Bhasin. It seems sensible that commercial actors, who likely have an expectation that their business partners will not cheat, lie, or deceive them, now know that this expectation is protected by the common law.

Fourth, the decision has brought Canadian common law in step with contract law in Quebec and the US. Given that these jurisdictions are common law Canada's largest trading partners, this is a positive development in terms of increasing the confidence of our investors and business partners in these jurisdictions, having consistent legal regimes across jurisdictions in the event of cross-border litigation and conflict-of-laws issues, and reducing differences that could protract negotiations over governing law clauses. 


\section{UnCertainty Post-Bhasin}

Despite its achievements, Bhasin also leaves several unanswered questions in its wake, which will undoubtedly have to be answered through extensive commercial litigation.

\section{A. Silence on the Pre-Contractual Stage}

Bhasin is notably silent on whether the good faith organizing principle gives rise to any duties of good faith or honesty when parties are negotiating an agreement. The decision focused on the actual performance of contractual obligations as opposed to the precontractual stage of negotiating them.

Courts have largely refused to recognize a duty to negotiate in good faith absent a special relationship such as the tendering of labour and employment contexts. The Supreme Court of Canada clarified this in Martel Building Ltd. v. Canada, in which Justices Iacobucci and Major explained:

[W] recognize that Martel's claim resembles the assertion of a duty to bargain in good faith. The breach of such a duty was alleged in the Federal Court, but not before this Court. As noted by the courts below, a duty to bargain in good faith has not been recognized to date in Canadian law. ${ }^{124}$

In Oz Optics, Timbercon, a defendant company which supplied technology to Lockheed Martin for the construction of fighter planes, had approached the plaintiff, Oz Optics, and asked it to provide automated attenuators on the promise that it would be the sole supplier. ${ }^{125}$ Timbercon nevertheless approached one of Oz Optics's competitors with an offer to produce the attenuators and sent both companies' bids to Lockheed Martin, who selected the competitor for its order. Oz Optics's claim for breach of the duty of good faith was dismissed, with the Court of Appeal relying on Martel for the principle that "the law has not recognized a general duty to bargain in good faith in contract." ${ }^{126}$ However, the Court of Appeal also noted that there is an exception when there is a special relationship between the negotiating parties, or parties are in a tendering process:

This court left open the possibility of a duty of good faith in bargaining in 978011 Ontario Ltd. $v$ Cornell Engineering Co., where the court said, "[a]bsent a special relationship, the common law in Canada has yet to recognize that in the negotiation of a contract, there is a duty to have regard to the person's interests, mainly, to act in good faith".

Courts have also recognized that a duty of good faith and fair dealing arises during the commercial tendering process. 
In the commercial tendering process, the obligation arises in the context of a model of imputed Contract $\mathrm{A} /$ Contract $\mathrm{B}$ between the parties. Contract $\mathrm{A}$ is formed upon the submission of a tender and requires fair dealing with respect to the consideration of all bids. Contract $B$ is the actual agreement entered into between the successful bidder and the party seeking the bids. ${ }^{127}$

Notwithstanding the courts' general reluctance to find a duty of good faith in negotiating contracts, there may be a shift in judicial attitudes in light of the recognition of the organizing principle of good faith in contractual performance. It is possible that the basic level of honesty and good faith that commercial parties reasonably expect in contractual dealings could be found to apply (at least to some extent) to the process of negotiating contracts. After all, the negotiation process is the very genesis of a contractual relationship. Can it really make sense that, once the parties sign up to a number of promises, they can reasonably expect honesty and fair play on each other's part, but that these expectations are somehow absent while they are negotiating those promises?

Lawyers and businesses alike will wait eagerly for the courts to visit the issue of good faith in contractual negotiation and to see to what extent, if any, Bhasin applies to create new pre-contractual duties.

\section{B. SCOPE AND APPLICATION OF Duty of Honest Performance}

Although Justice Cromwell interpreted the duty of honest performance as meaning "simply" that parties cannot lie or knowingly mislead each other about matters directly linked to the performance of a contract, there is more interpretive leeway available in the principle than might be apparent at first glance. Certainly, a consistent pattern of deception or misrepresentation will violate the duty, as was the case in Bhasin. However, there may be far more nuanced situations in which parties may truly find themselves in a dilemma.

For instance, we have yet to see how a court will treat a situation where one party to a contract asks the other about an issue and receives either no response or a refusal to provide an answer. Will silence be treated as misleading one's partner? In what circumstances? Adapting the facts in Bhasin, what if Can-Am had plotted with Hrynew to force Bhasin to merge his business (or, alternatively, to choose not to renew his contract), but, instead of lying to Bhasin repeatedly, had simply remained silent? Would Can-Am still have been liable? Bhasin does not answer this question because, although Can-Am was found to have

Ibid at paras 66, 68-69 [citations omitted]. Notably, in Empress Towers Ltd v Bank of Nova Scotia (1990), 73 DLR (4th) 400 (BCCA) [Empress Towers], the British Columbia Court of Appeal suggested that a renewal clause in a lease agreement suggested that the tenant could renew the lease at the prevailing market rate for rent, which must be mutually agreed between the landlord and tenant. The Court of Appeal held that this term carried with it an implied obligation for the landlord to negotiate in good faith with the tenant to agree on what the market rental rate was (ibid at paras 9-10). The implication from this case is that, where a contract contains terms related to negotiation, duties of good faith can be read into that process. Subsequent authorities have cast doubt on this decision, with the British Columbia Court of Appeal most recently citing to case law that suggests Empress Towers "should be regarded as confined to its very narrow set of facts, and not as authority for a general proposition that the duty to bargain in good faith exists whenever a negotiation takes place within an existing contract" (Brule v Rutledge, 2015 BCCA 25, 70 BCLR (5th) 291 at para 49, citing EdperBrascan Corp v 117373 Canada Ltd (2000), 50 OR (3d) 425 at para 49). 
"equivocated" when Bhasin asked about its intentions with respect to the merger, ${ }^{128}$ it was also found to have explicitly misled him on several occasions. ${ }^{129}$

Furthermore, the Supreme Court held that parties may be able to relax the duty of honest contractual performance with express terms in their contract. The Court was presumably upholding parties' freedom to contract when describing this limitation on the duty of honesty. However, the Court's lack of specificity as to how exactly the duty of honest performance can be contractually relaxed means that parties and their counsel are left to guess what kind of contractual clauses will pass judicial scrutiny. For more definitive guidance, we must await the results of future litigation over parties' attempts to "relax" the duty of honesty, and courts will have to do their best in the meantime to assess whether such clauses are sufficiently express and appropriate to qualify as legitimate relaxations.

\section{UnCertainty About the Good Faith Principle}

Although the Court did provide for parties to relax the duty of honesty, it did not explicitly create such a proviso for other duties that have been subsumed under the organizing principle of good faith. Consequently, we are left to speculate as to which duties derived from the good faith principle can be relaxed, and which ones, if any, are so sacrosanct as to be unmalleable. Presumably, in contractual contexts where there is a judicially-recognized power imbalance between the contracting parties, such as in the insurance, employment, and landlord-tenant contexts, duties to act in good faith will be unshakeable. However, it seems reasonable that sophisticated commercial parties would be able to relax other good faith obligations with express language. For instance, this paper discusses cases where there is an implied duty of good faith arising from clauses that suggest cooperation between the parties. Notwithstanding such a clause, if parties have express terms that delineate the extent of cooperation required, this would presumably relax a court's vigilance about whether a party has breached its good faith obligations.

\section{Lessons for Parties Signing Contracts GOVERNED BY CANADIAN COMMON LAW}

In light of Bhasin, parties entering into contracts that are governed by Canadian common law will want to take the following steps to ensure they are appropriately managing risk and complying with their good faith obligations.

First, Bhasin is unequivocal that lying or misleading another party to a contract will constitute a breach of the duty of honest performance and, therefore, a breach of the contract. It is no longer sufficient to simply comply with a contract's strict terms. Significantly, even statements that are not lies, but that could be viewed as misleading, may constitute breaches of the duty. Parties must be cautious to avoid making any communications or representations to each other that could reasonably be construed as breaching the duty of honesty, and counsel should advise their clients accordingly. An effective means of exercising this caution may be to set up a system for counsel to vet communications with one's counterparty through 
counsel for accuracy. Communicating "off the cuff" or having excessive points of contact (where information may be inadvertently conveyed in a misleading way) should be avoided. Moreover, material communications with one's counterparty should be documented carefully to create an evidentiary record.

Second, since the Supreme Court held that parties can relax the duty of honest performance through express contractual terms, it would be prudent to negotiate clear parameters for how the duty will apply when forming a contract. Given that it is uncertain how far courts will allow parties to relax the honesty duty, until this is determined in case law, it will likely be advisable to reduce litigation risk by including a clause or clauses in contracts clarifying the circumstances in which the duty will and will not arise. For instance, one might include a clause stating that a failure by one party to provide information to the other that is not otherwise required will not constitute deception or a breach of the duty of honesty, as long as no misleading information is communicated.

\section{CONTRACTS IN THE ENERgy SeCtor}

Bhasin and its potential consequences have already engendered significant discussion and commentary among practitioners in the energy sector. Until the legal principles from Bhasin are developed further, practitioners can only speculate on how Bhasin will impact contractual performance and the evolution of good faith-related contractual terms. In the meantime, practitioners will simply need to make best efforts to advise clients with existing agreements how best to adhere to the good faith principle. Lawyers will face a fresh set of challenges when it comes to drafting new agreements in light of the good faith organizing principle and, where appropriate, developing provisions that relax the duty of honest performance.

In light of Bhasin, certain contractual performance provisions in energy sector agreements may be more likely than others to form the basis of a good faith litigation claim. Accordingly, this section of the article will focus on those agreement terms that we consider most likely to attract a claim of breach of good faith or breach of the duty of honesty. Our predictions are based on the existence of terms that are relevant to the Court's rationale in Bhasin. They may be present either in a key clause or more broadly throughout the contract, or they may be inherent in the relationships governed by such clauses. We have identified these special elements as follows: (1) an imbalance of information; (2) the vulnerability of one party to an abuse of discretion by the other party; and (3) the potential for the evisceration of rights despite technical compliance with the express provisions of the subject agreement. However, unlike the agreement at issue in Bhasin, given the relevance to the duty of honesty, we have added an additional element to our screen of potentially impacted agreement terms: (4) an express disclosure obligation.

We have focused our commentary on specific illustrative clauses and relationships containing the described elements. These are: (1) rights of first refusal (ROFR) jurisprudence and clauses; (2) authorizations for expenditures; and (3) accounting and remittance of production sale proceeds. While we have focused on only some forms of these identified subject matter clauses, we expect that our commentary can be applied to an analysis of all such clauses, subject, of course, to specific drafting differences. Further, we hope that our 
commentary will also be useful to the reader in considering subject matter clauses not specifically addressed here.

\section{A. Right OF First RefuSAL}

Compliance with ROFR provisions is often the source of disagreements between parties. However, those disagreements have only occasionally led to litigation and the furtherance of Canadian jurisprudence with regard to the interpretation and construction of such provisions and their contractual performance. Not unlike Canadian jurisprudence prior to Bhasin with respect to a potential duty of good faith, Canadian courts have not been consistent in how they have construed ROFRs. As noted by previous commentators, "ROFRs are one of a select few contractual arrangements which have been treated by the courts in ways that are distinct from those applied to standard 'commercial documents." "130 This comment reflects the difficulty in interpreting ROFR provisions given that Canadian courts have taken a broad and purposive approach in some cases, while, in others, they have applied a narrow, strict construction.

Some may question whether Bhasin is a significant development in respect of ROFRrelated contractual obligations. In fact, while there have been differences in approach, the courts have generally refused to allow the party owing the ROFR obligation (the grantor) to exercise its discretion in a way and for the purpose of eviscerating the entitled party's (the grantee's) ROFR rights. Such decisions have been reached either by recognizing an implied duty of good faith or on some other basis rooted in the terms of the agreement or common law, even where the exercise of discretion is in strict technical compliance with the terms of the agreement. Canadian case law regarding ROFRs has demonstrated the courts' desire to ensure that some degree of good faith (or at least an absence of bad faith) is imposed on the grantor owing the ROFR to the grantee. GATX and subsequent cases have indicated that courts will not accept transactions which are contrived by parties to do indirectly what they cannot do directly, but they will allow transactions to proceed which have legitimate business purposes and which are not simply structured so as to circumvent another party's pre-emptive rights. ${ }^{131}$ While refusing to go so far as to find a free-standing duty of good faith, the Alberta Court of Appeal in Sunoma cited GATX in finding that "[i]t is clear that the grantor of a ROFR has a duty to exercise its rights in such a manner to ensure that the other party's rights are not rendered meaningless." 132 Further, where the contract creates reasonable expectations and performance standards that are consistent with wellestablished industry practices and the express terms of the contract, the courts will enforce those expectations. ${ }^{133}$ The expression of this obligation in the context of a newly recognized duty of honesty is helpful in ensuring that both the grantor and the grantee understand that they must perform their respective obligations and exercise their respective rights honestly. Bhasin clarifies that this duty of honesty applies regardless of whether or not such obligations and rights were promised or granted on the express basis that they be exercised in a bona fide

Clifford D Johnson \& David J Stanford, "Rights of First Refusal in Oil and Gas Transactions: A Progressive Analysis" (1999) 37:2 Alta L Rev 316 at 322.

131 GATX, supra note 35. See also Chase Manhattan Bank of Canada v Sunoma Energy Corp, 2002 ABCA 286, 317 AR 308 [Sunoma]; Glimmer Resources Inc v Exall Resources Ltd (1997), 35 BLR (2d) 297 (Ont Ct J (Gen Div)). 
manner. This is particularly relevant in the upstream oil and gas sector where contractual relationships have been formed under, or significantly influenced by, the Canadian Association of Petroleum Landmen Operating Procedures (the CAPL Procedures), ${ }^{134}$ which, in varying degrees and in different applications, contain a "bona fide" requirement. With respect to the CAPL Procedures' forms of ROFR clauses, while earlier versions expressly applied this concept to certain limited obligations of the grantee (the obligation to provide a bona fide allocation of value or consideration in cash when disclosing the terms of the potential ROFR transaction), the 2007 Procedure expressly incorporated numerous references to an obligation to act bona fide in the performance of ROFR obligations by grantor. ${ }^{135}$

The Supreme Court of Canada has not articulated a catch-all definition of "bona fide," but rather, has only articulated its definition in certain contexts. ${ }^{136}$ While the English courts have also adopted a contextualized approach to the term, they have stated that the term has some fundamental meaning along the lines of "honestly."137 Legal dictionaries confirm this definition. ${ }^{138}$ Interestingly, it appears that the recognition of a duty of honesty in contractual performance, at least insofar as it applies to ROFRs in the upstream sector of the oil and gas industry, accords with industry expectations given the aforementioned adoption of a bona fide standard of performance throughout the ROFR provisions contained in the 2007 Procedure.

With respect to commonly used ROFR provisions, there are two primary areas of application of the duty of honesty: (1) exemptions or exceptions to the application of the ROFR to the proposed transaction; and (2) where the ROFR applies, disclosure of the disposition terms to the grantee. For purposes of this analysis, we will concentrate our comments on the heavily used 1990 Procedure.

Practitioners familiar with the 1990 Procedure will be at least generally aware of the exemptions or exceptions to the ROFR contained therein. Those practitioners experienced in handling acquisition and divestiture transactions will be familiar with the ways in which such exemptions and exceptions can be technically complied with in letter but breached in spirit. Similarly, there is likely not an oil and gas transactions lawyer who has not had to counsel a vending client (or purchaser client), who is otherwise determined to aggressively allocate value or consideration to a ROFR asset, to ensure that its allocation is done on a

134 Canadian Association of Petroleum Landmen, 1971 Operating Procedure (Calgary: CAPL, 1971); Canadian Association of Petroleum Landmen, 1974 Operating Procedure (Calgary: CAPL, 1974) [1974 Procedure]; Canadian Association of Petroleum Landmen, 1981 Operating Procedure (Calgary: CAPL, 1981); Canadian Association of Petroleum Landmen, 1990 Operating Procedure (Calgary: CAPL, 1990) [1990 Procedure]; Canadian Association of Petroleum Landmen, 2007 Operating Procedure (Calgary: CAPL, 2007) [2007 Procedure].

135 See 2007 Procedure, ibid, cl 24.01, which expressly requires that: (i) each type of transaction structure that constitutes an exception to the ROFR must be bona fide; (ii) the disposition itself be bona fide; and (iii) the provision by disposing the owner of its bona fide estimated value or allocation of value in cash. See e.g. Zurich Insurance Co v Ontario (Human Rights Commission), [1992] 2 SCR 321 for its definition in relation to the Human Rights Code, 1981, SO 1981, c 53.

See The Queen v Holl (1881), 7 QBD 575 (CA).

See e.g. Black's Law Dictionary, 10th ed, sub verbo "bona fide": "1. Made in good faith; without fraud or deceit. 2. Sincere; genuine." See also Black's Law Dictionary, 6th ed, sub verbo "bona fide": "In or with good faith; honestly, openly and sincerely; without deceit or fraud." 
basis that is reasonable and defensible. Bhasin should, at the very least, serve as an authority from which practitioners will steer their clients away from that cliff's edge.

If we are to assume that the ROFR provisions of the 2007 Procedure are reflective of the commonly held expectations of industry participants, the recognition of a duty of honest performance by Bhasin effectively catches the common law up with those expectations. However, under the 2007 Procedure, there is also a requirement on the grantor's part to disclose certain information and an understanding that the grantee is relying upon such information to assess the validity of the grantor's claim of an applicable exception or to understand and assess the true transaction terms in making an informed ROFR decision. While the Supreme Court was clear in Bhasin that it did not impose a duty of disclosure, in cases where there is an express contractual duty of disclosure, it seems reasonable to expect that Bhasin will require, as part of the duty of honesty, that the manner of that disclosure is upfront, honest, and thorough, and will not permit a grantor to mislead a grantee by omitting any information or facts relevant to the grantee in assessing the validity of an exception claim or value allocation or the terms of a proposed transaction. This may be particularly the case with the 1990 Procedure, which requires the grantor to provide the essential terms or facts of the proposed disposition and "any other information respecting the transaction which the disposing party reasonably believes would be material to the exercise of the offeree's rights hereunder." $" 139$

The Alberta Court of Appeal in Sunoma considered the 1974 Procedure's ROFR provision related to the bona fide allocation of the cash value or a portion of the cash consideration to certain ROFR assets. ${ }^{140}$ The Court of Appeal considered whether the purchaser of the asset, Eravista, owed the grantee (to whom Eravista had no direct contractual obligation) a duty of good faith or if it was required to act bona fide in estimating the value of the ROFR assets. The Court of Appeal indicated that, even if it was to assume that Eravista owed the grantee some kind duty:

\footnotetext{
Eravista's mere refusal to reveal its methodology or to answer questions about the way in which it had valued other lands in the package does not establish a lack of bona fides. Best took no legal steps (other than the present proceedings, commenced after the passage of the 20 days mentioned in the ROFR notice) to force Eravista to reveal its valuation methodology. Nor did it take legal steps to compel Anderson to answer some of the questions put to him in cross-examination on his affidavit. These circumstances greatly weaken Best's claim that Eravista's actions prove male fides. Furthermore, according to Anderson's cross-examination, the data used by Eravista was in the public domain; only the method of using and interpreting that data was confidential to Eravista. ${ }^{141}$
}

Assuming the Court's rationale in Sunoma is followed, a grantee alleging that a grantor has not fulfilled its duty of honesty with respect to a claimed exemption or value allocation will have the burden of proof. Sunoma suggests that the complaining party in such circumstances should be extremely diligent and timely in registering its objection and the grounds therefor, and in pursuing, whether through legal steps or otherwise, disclosure of 
relevant facts and answers. Given the Court's confirmation in Bhasin that the duty of honesty did not include an additional duty of disclosure, it will be interesting to see whether a grantor attempting to sell a ROFR asset will be emboldened to refuse to provide any further disclosure to a grantee on the basis that it has already fully complied with its express disclosure obligations under the 2007 Procedure.

An additional implication of Bhasin in respect of ROFR provisions is that the grantee must also act honestly in the exercise and performance of its contractual rights and obligations related to a proposed disposition by the grantor. A grantee that objects to such disposition, whether through the challenge of the ROFR notice or on some other basis, is now also required to exercise its contractual rights to challenge, hinder or block the transaction in accordance with its duty of honesty - it must not be doing so primarily for strategic reasons, commercial advantage or to be a nuisance. Even disregarding the potential for an award of punitive damages, a grantee found in breach of this duty may face a significant adverse damages award in the event its actions delay or prevent the grantor and the proposed purchaser from completing the transaction, since a delayed or terminated transaction, combined with changes in market conditions, could produce a diminution of value, an increase in transaction financing costs, a loss of business opportunity, or other material adverse consequences.

\section{B. AUTHORIZATIONS FOR EXPENDITURE}

Major projects in the energy sector require extremely large capital investment. In order to finance such capital programs, project proponents, particularly upstream oil and gas operators, have increasingly turned to utilizing joint ventures to obtain such required capital and to share risk with other investors. While joint ventures have formed part of the oil and gas commercial landscape for decades, in the past ten years we have seen an increase in the popularity of financing such upstream development through the use of major joint ventures in a variety of forms, including incorporated joint ventures, unincorporated joint ventures, and partnerships.

All joint ventures involve the approval and funding of multi-year development programs, frequently through mechanisms using annual work programs and budgets and single operation authorizations for expenditures (AFE). The partners in such joint ventures often include investors with little or no operational ability in Western Canada, who may have limited expertise in the exploitation of resources generally, or who may have a limited understanding of the joint venture assets, the regulatory landscape, the relevant exploitation methods, processes and technologies, the environmental considerations, and the other key operational matters. As a result, these funding parties rely heavily on the project proponent or operator to disclose all relevant information related to assessing and approving development programs and authorities for expenditure and to keep them properly informed and notified as to conduct and results of operations including the accurate and transparent disclosure of capital and operating costs. Often joint venture arrangements will include a management committee where such information will be provided and funding- and operations-related decisions will be made. The duty of disclosure and specific requirements of disclosure by the operator that are often set out in the relevant joint venture agreement will typically require significantly more disclosure than the standard CAPL Procedure. 
Bhasin makes clear that such disclosure must not be done so as to knowingly mislead the recipient. Doing so in the context of decisions involving the deployment of tens or hundreds of millions of dollars of capital is obviously fraught with peril, particularly having regard to the uncertainty of success in exploring, developing, and exploiting natural resources, the variables and uncontrollable aspects of doing so, and the accuracy of hindsight in assessing the merits of an already completed course of action. Accordingly, Bhasin will likely lead to some tension in the negotiation of joint venture agreements between the operator wanting to protect itself by limiting what it must disclose to non-operators, and non-operators wanting to be fully informed of joint venture related business to ensure good decision-making. In addition, in some cases, disclosure can undermine the best interests of one or all of the joint venture partners. For example, for many reasons, the competitive nature of the oil and gas industry sometimes requires a guarded approach to the disclosure of sensitive information. Further, the speculative nature of oil and gas developments is such that new processes, technologies and approaches are continually being developed, tested, and proven or discarded. Will fear of breaching the duty of honesty inhibit the sharing of ideas and information between partners who may become cautious in volunteering a little information (perhaps, for example, the sharing of encouraging results from a new process or technology on an unrelated project) if they believe that doing so obligates them to disclose everything that could be directly relevant to such initial disclosure?

The creation and existence of management committees under joint venture agreements may also be problematic. If a management committee is established for the overall supervision and direction of the development of the subject assets and for approving and directing the implementation of development programs, does this require management committee members to be honest as to why they wish to approve or not approve certain development activities? What if the reason a partner does not want to proceed with an aggressive capital intensive development phase is wholly unrelated to the merits of the development activities? Common examples of such reasons include an unannounced change in corporate strategy, the subject asset no longer being considered a high priority, or an ulterior motive to monetize assets, such as early stage financial distress. Must a committee member now disclose this information? Undoubtedly it would impact the other partner's plans for the asset and how it might eliminate or mitigate the consequences of the first party's strategy beyond the immediate mothballing of a proposed development initiative. Bhasin raises the question of whether the mere creation of a communication venue between the parties in the form of a management committee, where open discussion in furtherance of the best interests of the joint venture is intended, results in the imposition of the duty of honesty in respect of those communications.

\section{ACCounting And RemitTance of Production Sales Proceeds}

Under Article VI of the 2007 Procedure, the operator has the right, in circumstances where another party fails to take its share of production in kind, to either purchase such party's share of production or to sell it on their behalf at a "market price."142 The different forms of the CAPL Procedures have different ways of addressing how this price is to be 
determined and what latitude the operator has in exercising its discretion in selling or purchasing such production. Bhasin clearly establishes that, in selling such share of production to a third party or purchasing the same for its own account, regardless of the applicable form of CAPL Procedure, the operator must do so honestly in all cases. The general imposition of a duty of honesty may assist users of earlier versions of the CAPL Procedures, which lack the specific provisions and protections of later CAPL Procedures, by more generally addressing the risk of an operator being selective in determining the price by, for example, including structured pricing arrangements or "incorporating out-of-the-money hedging contracts into the calculation of Market Price."

The operator has various degrees of discretion under the CAPL Procedures in exercising its right to sell such production to a third party or purchase it for its own account. In light of that discretion, it is important to remember that the duty of honesty described by the Court in Bhasin does not require the operator "to forego advantages flowing from the contract; it is a simple requirement not to lie or mislead the other party about one's contractual performance." "144 Accordingly, in determining the price of such production that it purchases for its own account, while such price is expressly required to be reasonable (whether expressly or impliedly required under the CAPL Procedures) and the operator must be honest in exercising such discretion, Bhasin does not otherwise diminish whatever latitude the operator has under the applicable CAPL Procedure to establish such price based on marketrelated factors, whether as specified in the applicable CAPL Procedure or otherwise.

Furthermore, the Court's reasoning in Bhasin supports the position that, if the operator is honest in arriving at a reasonable price and exercising its rights and discretion in purchasing such production, it is not a breach of the duties recognized under the good faith principle, regardless of the commercial advantage the operator enjoys. For example, in determining the "market price" it is willing to pay, the operator can take into account, among other things, market factors such as the point of sale and the type of and costs for using transportation service available for the delivery of such substances. The CAPL Procedure does not require an operator, if selling to a third party, to obtain the best price or, if purchasing for its own account, to pay the best price, but merely to obtain or pay a reasonable price having regard to applicable market factors. Bhasin has not changed this.

\section{DRAFTING ENERgy CONTRACTS IN LIGHT OF BHASIN}

The CAPL Procedure is a useful place to start when considering how contracting parties may try to relax, limit, or otherwise define their obligations in respect of the duty of honest performance. Clause 1.05 of the 2007 Procedure expressly addresses the concepts of trust, partnerships, fiduciary relationships, and the duty of good faith. ${ }^{145}$ In summary, clause 1.05 attempts to expressly negate any joint, collective or joint and several liabilities, any formation of partnership or creation of partnership duties, and any general application of any trust duties or fiduciary relationships (with noted exceptions). In addition, it expressly provides that each party is free to conduct its business as it sees fit, including in competition 
with "Joint Operations," subject to the imposition of a trust, trust duty or fiduciary relationship by law or by equity, and subject to any duty of good faith (or similar duty) that may otherwise apply at law or in equity.

Not surprisingly, clause 1.05 under the 2007 Procedure does not relax the duty of honest performance in any way. As Bhasin did not then exist, the drafters did not put their minds to that issue. Further, and also not surprisingly, no such specific relaxation of the "bona fide" requirements contained in the ROFR provisions or other specific provisions was provided for in the 2007 Procedure.

In considering the decision in Bhasin, it appears that drafters of future versions of the CAPL Procedure (and other energy sector agreements) could attempt to relax the requirements of the honesty duty in at least two ways: (1) by augmenting Clause 1.05 such that the attempted relaxation applies generally to all covenants under the Operating Procedure; and (2) by expressly addressing the relaxation of the duty of honesty within individual clauses. Lawyers face the daunting task of effectively relaxing the duty of honest performance while preserving its core requirements.

Because the Court in Bhasin expressly stated that the duty of honest performance is distinct from a duty of disclosure, it would appear that drafters of energy contracts could revise contractual disclosure obligations with a view to restricting or defining the parameters and the extent of required disclosure, the means of disclosure, and the recipient's entitlement to receive information or to request additional information. By tackling the contractual disclosure obligations, drafters may thereby be able to indirectly "relax" the duty of honesty while still continuing to meet its core requirements. For example, we may see efforts to relax or bolster the duty of honesty by way of some of the following:

1. The establishment of a rigid process and appointment of specific designated representatives through whom all communications must flow, and the express negation of any right to rely on communications from a counterparty delivered through any other unauthorized means or personnel.

2. The adoption of specific, mandated, forms-based disclosure specifically outlining the information and categories of information required to be disclosed and to which the recipient is entitled.

3. A general exclusion for "proprietary, confidential and competitive information" of a specifically defined nature.

4. A general exclusion of information related to business strategies of a specifically defined nature that are not directly or primarily related to the conduct of "Joint Operations" or the subject matter of the agreement.

5. An express, finite listing of the information that must be disclosed and to which a counterparty is entitled.

6. The express adoption of an industry standard approach (or a few alternative industry standard approaches, one of which would be elected upon at the time of execution of 
the agreement) to the exercise of a discretion such as, for example, the determination or allocation of value or cash consideration to a ROFR asset by such recognized methodology.

7. Express required disclosure of evidence with respect to the basis on which a discretion is exercised, including, for example, how a ROFR asset is valued or consideration is allocated to it and the provision of appropriate back-up information, related analysis, and justification.

8. Indemnification in lieu of providing evidence supporting the reasonable exercise of discretion including, for example, with regard to the structuring of a transaction which falls within a ROFR exception or the use of discretion in allocating value or consideration to a ROFR asset, a mechanism either requiring or deeming of the delivery by grantor of a warranty confirming that it has exercised its discretion and performed its ROFR obligations in accordance with the duty of honesty (or on a bona fide basis) and indemnifying the grantee for all costs and losses (unlimited by amount or by type) resulting from any breach thereof.

9. The general adoption of the right to make elections in such party's sole discretion and the right to withhold reasons for such election or provide inaccurate reasons, provided that the party exercising such right does not mislead the other party as to its intention with respect to making such election.

10. An exclusion with respect to any information, that upon disclosure to the counterparty, would require public disclosure under governing law, including securities laws and the rules of any applicable stock exchange.

Regardless of how practitioners attempt to address good faith and the duty of honesty with new contractual provisions, what is clear is that there will be efforts to do so given the issues raised by Bhasin. New practices and approaches will emerge and evolve, with varying degrees of effectiveness. Unless and until recognized best practices emerge, those approaches will vary from organization to organization and possibly from department to department within a single organization. Like other contractual provisions, different best practices may emerge for different types of agreements and in different situations. Real world situations and further judicial direction will hone practitioners' thinking and highlight issues and circumstances that are difficult to anticipate while the full implications of Bhasin remain unclear.

\section{Conclusion}

Bhasin will undoubtedly have a profound impact upon Canadian contract law and the way parties entering agreements conduct themselves. This is not to say that commercial activity pre-Bhasin was rife with dishonesty or bad faith. Rather, the explicit recognition of several duties under the good faith principle will understandably result in parties making every effort to ensure they are complying with those duties. Canadian courts are now tasked with developing and interpreting Bhasin in a way that respects the importance and utility of the good faith principle without opening the floodgates to meritless or abusive litigation. 